\title{
Detecting asymptomatic carriage of Plasmodium falciparum in southern Ghana: utility of molecular and serological diagnostic tools
}

Hamza B. Agbana ${ }^{1,2}$, Eric Rogier ${ }^{3}$, Aminata Lo', Zakaria Abukari' ${ }^{1}$, Sophie Jones ${ }^{3}$, Ben Gyan', Michael Aidoo ${ }^{3}$ and Linda E. Amoah ${ }^{1 *}$

\begin{abstract}
Background: Asymptomatic malaria infections can serve as potential reservoirs for malaria transmission. The density of parasites contained in these infections range from microscopic to submicroscopic densities, making the accurate detection of asymptomatic parasite carriage highly dependent on the sensitivity of the tools used for the diagnosis. This study sought to evaluate the sensitivities of a variety of molecular and serological diagnostic tools at determining the prevalence of asymptomatic Plasmodium falciparum parasite infections in two communities with varying malaria parasite prevalence.
\end{abstract}

Methods: Whole blood was collected from 194 afebrile participants aged between 6 and 70 years old living in a high (Obom) and a low (Asutsuare) malaria transmission setting of Ghana. Thick and thin blood smears, HRP2 based malaria rapid diagnostic test (RDT) and filter paper dried blood spots (DBS) were prepared from each blood sample. Genomic DNA was extracted from the remaining blood and used in Plasmodium specific photo-induced electron transfer polymerase chain reaction (PET-PCR) and Nested PCR, whilst the HRP2 antigen content of the DBS was estimated using a bead immunoassay. A comparison of malaria parasite prevalence as determined by each method was performed.

Results: Parasite prevalence in the high transmission site of Obom was estimated at $71.4 \%, 61.9 \%, 60 \%, 37.8 \%$ and $19.1 \%$ by Nested PCR, the HRP2 bead assay, PET-PCR, HRP2-RDT and microscopy respectively. Parasite prevalence in the low transmission site of Asutsuare was estimated at $50.1 \%, 11.2 \%, 5.6 \%, 0 \%$ and $2.2 \%$ by Nested PCR, the HRP2 bead assay, PET-PCR, RDT and microscopy, respectively. The diagnostic performance of Nested PCR, PET-PCR and the HRP2 bead assay was similar in Obom but in Asutsuare, Nested PCR had a significantly higher sensitivity than PET-PCR and the HRP2 bead assay, which had similar sensitivity.

Conclusions: Nested PCR exhibited the highest sensitivity by identifying the highest prevalence of asymptomatic $P$. falciparum in both the high and low parasite prevalence settings. However, parasite prevalence estimated by the HRP2 bead assay and PET-PCR had the highest level of inter-rater agreement relative to all the other tools tested and have the advantage of requiring fewer processing steps relative to Nested PCR and producing quantitative results.

Keywords: Malaria, Bead-based multiplex, HRP2, PET-PCR, Asymptomatic, RDT, Microscopy

*Correspondence: lamoah@noguchi.ug.edu.gh

${ }^{1}$ Immunology Department, Noguchi Memorial Institute for Medical

Research (NMIMR), University of Ghana, Accra, Ghana

Full list of author information is available at the end of the article original author(s) and the source, provide a link to the Creative Commons licence, and indicate if changes were made. The images or other third party material in this article are included in the article's Creative Commons licence, unless indicated otherwise in a credit line to the material. If material is not included in the article's Creative Commons licence and your intended use is not permitted by statutory regulation or exceeds the permitted use, you will need to obtain permission directly from the copyright holder. To view a copy of this licence, visit http://creativecommons.org/licenses/by/4.0/. The Creative Commons Public Domain Dedication waiver (http://creativeco mmons.org/publicdomain/zero/1.0/) applies to the data made available in this article, unless otherwise stated in a credit line to the data. 


\section{Background}

Asymptomatic parasite carriage in Plasmodium falciparum infections is a well-known phenomenon [1]. Previously, it was assumed that residents of high transmission areas were at a greater risk of harboring asymptomatic (subclinical) infections as a result of acquired immunity to clinical malaria developed over repeated exposures [1, 2]. However, recent studies conducted in low-transmission areas of malaria endemic countries, especially in Africa have identified a high prevalence of asymptomatic P. falciparum carriers [3]. Asymptomatic Plasmodium carriage in low transmission settings has been suggested to be responsible for $20-50 \%$ of all malaria transmission in those settings [4].

Recent estimates of high asymptomatic parasite carriage in low transmission settings could be due to the sensitivity of the parasite detection tools used, where highly sensitive molecular tools increase parasite prevalence estimates [5]. Light microscopy, the gold standard for laboratory confirmation of malaria [6] has a sensitivity of detection ranging from 30 to 50 parasites per microliter (p/ $\mu \mathrm{L})$ of blood [7] to $50-500 \mathrm{p} / \mu \mathrm{L}$ [6]. In addition to having low sensitivity, microscopy is dependent on the quality of reagents and the techniques used in preparing and staining the smear [8] as well as the expertise of the microscopist who examined the smear [9]. These limitations and the difficulty of deploying microscopy to all testing sites have led to the expansion of tools used in malaria diagnosis and detection of infection to include tools such as rapid diagnostic test (RDT) kits, with a sensitivity of $\sim 100 \mathrm{p} / \mu \mathrm{L}[6,9]$ and molecular tools such as polymerase chain reaction (PCR), with a sensitivity of about $2-5 \mathrm{p} / \mu \mathrm{L}$ of blood for Nested PCR [10] and 0.01 to $1 \mathrm{p} / \mu \mathrm{L}$ of blood for real- time PCR [11].

Although the main rationale to improve malaria diagnostic tools is to ensure prompt and accurate parasite detection and treatment of clinical cases, the new diagnostic tools are frequently used by Malaria Control Programmes to assess parasite carriage in population surveys $[5,12,13]$.

Malaria RDT kits are predominantly based on the detection of $P$. falciparum histidine-rich protein (HRP2) and/or Plasmodium lactate dehydrogenase (LDH) antigens, and despite RDT kits having a similar sensitivity to microscopy [14-16], their ease of use and fast turnaround time have made them a preferred diagnostic tool $[17,18]$. The most commonly used malaria RDT kits are the HRP2-based tests, because of the abundant production of the HRP2 protein by the parasite and its enhanced sensitivity compared to LDH based RDT kits $[19,20]$. A major limitation of RDT kits is that they are not quantitative [21]. Additional limitations of HRP2 RDT kits include the persistence of HRP2 antigen in the blood for up to four weeks after the clearance of an active infection, which results in high false-positive rates [22] and the increasing reports of false-negative results due to the presence of parasites not producing HRP2 as a result of pfhrp 2 gene deletions [23].

A recently developed tool for detecting parasite antigen is a sensitive HRP2 bead assay, which can simultaneously measure multiple parasite antigens including HRP2, LDH and aldolase. The HRP2 bead assay has a limit of detection of $0.24,1.43$ or $71.9 \mathrm{pg} / \mathrm{mL}$ for three unique forms of HRP2 antigens (Type A, B, and C, respectively) that are captured by the beads [24]. The main disadvantage of the HRP2 bead assay is that it cannot be used as a point of care test [24-26].

Molecular diagnosis of malaria largely comprises of the use of a wide variety of polymerase chain reaction (PCR) platforms to detect parasite nucleic acids. A photoelectron induced transfer PCR (PET-PCR), has a limit of detection of 3.2, 5.8, 3.5 and $5 \mathrm{p} / \mu \mathrm{L}$ for P. falciparum, Plasmodium ovale, Plasmodium malariae and Plasmodium vivax, respectively, and the possibility of multiplexing, which allows the detection of both P. falciparum and another human Plasmodium species in a single reaction [27]. PET-PCR has also been optimized for use in detecting asymptomatic malaria parasite carriers in large community surveys [24]. Although molecular tools are more sensitive than microscopy and RDTs, they are not suitable for point of care diagnosis as they are time-consuming and require expensive specialized equipment and reagents as well as highly-skilled personnel to run them [10].

This pilot study evaluated the utility of a variety of malaria parasite detection tools; microscopy, HRP2based malaria RDT, HRP2 bead assay, PET-PCR and Nested PCR in determining the prevalence of asymptomatic $P$. falciparum parasite carriage amongst participants from two communities with varying malaria parasite prevalence in southern Ghana.

\section{Methods}

\section{Ethical consideration}

Ethical approval for the study was obtained from the Institutional Review Board of the Noguchi Memorial Institute for Medical Research (NMIMR), Ghana (Study number 089/14-15). Written informed consent, assent and parental consent (for children) were obtained from all study participants.

\section{Study site and population}

This pilot study used consecutive sampling to select 194 participants from a larger cross-sectional study conducted in Obom and Asutusare during the off-peak malaria season (February 2016) [28]. Participants from 
the larger study were aged between 6 and 70 years old and selected based on the absence of any sign or symptom suggestive of malaria.

Obom is a high malaria parasite prevalence setting in the Ga South municipality of Greater Accra Region of Ghana (Fig. 1) with a microscopy estimated parasite prevalence of $35 \%$ in 2014 [5, 12] and 41.8\% in 2019 [29]. Asutsuare is a low malaria parasite prevalence setting in the Shai Osudoku District of the Greater Accra Region of Ghana. Microscopy estimates of parasite prevalence in Asutsuare were $8.9 \%$ in 2009 [30] and 3.6\% in 2016 [31]. According to the World Health Organization (WHO), an annual parasites prevalence of $1-10 \%$ is considered as low and $\geq 35 \%$ considered as high [32].

\section{Sample collection and processing}

Before sample collection, the axillary temperature of each participant was measured using a digital thermometer. Venous blood $(5 \mathrm{~mL})$ was collected from each volunteer into EDTA vacutainer ${ }^{\circledR}$ blood collection tubes (BD,
New Jersey, USA). An aliquot of the blood was used to prepare thick and thin blood smears for microscopy. The blood smears were air dried, fixed (thin- film only) and stained with Giemsa following the WHO standard protocol $[8,33]$. The slides were observed at $100 \mathrm{X}$ magnification under a light microscope by two microscopists working independently. A sample was scored as negative for malaria if no parasite was seen after observing 200 fields and scored positive if parasites were observed. Parasite density, destimated as the number of parasites per microlitre blood $(\mathrm{p} / \mu \mathrm{L})$ was determined as the number of malaria parasites observed per 200 white blood cells (WBCs) X 40, with the assumption that $1 \mu \mathrm{L}$ of blood contains 8,000 WBCs [34].

Additionally, $5 \mu \mathrm{L}$ of the blood was used for $P$. falciparum diagnosis using the Malaria Pf (HRP2) Ag RDT Multi Kit (Access Bio Inc, New Jersey, USA), following the manufacturer's instructions.

Four, $50 \mu \mathrm{L}$ drops of blood sample were spotted on Whatman \#3 filter paper (GE Life sciences, USA). The

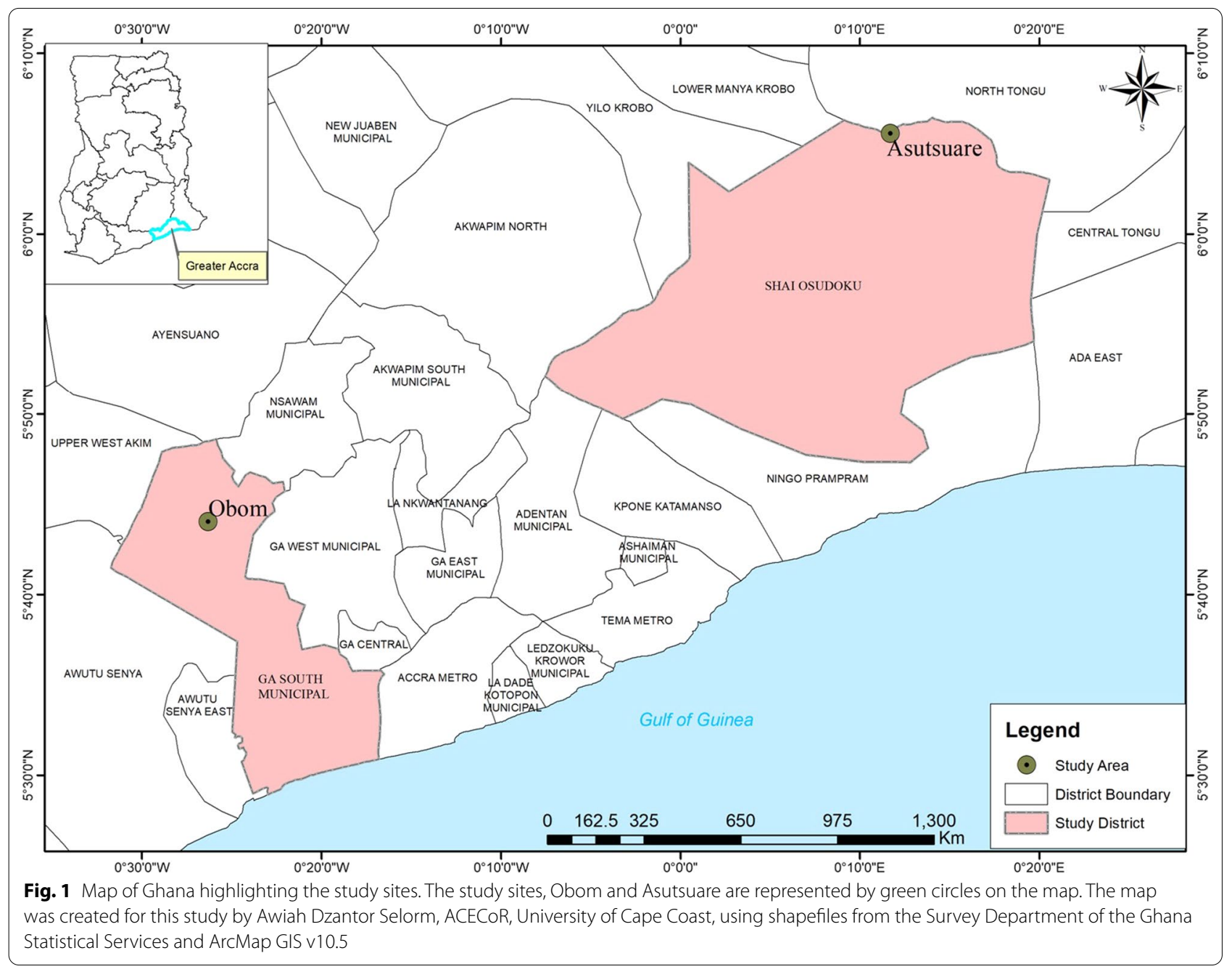


filter paper blood spots were individually air dried and stored at room temperature in a sealed plastic bag containing a desiccant. The remaining blood from each volunteer was separated into plasma and packed blood cells, which were subsequently stored frozen at $-20{ }^{\circ} \mathrm{C}$ until required. All samples from the field were subsequently transported to the Immunology Department of the NMIMR, Ghana for further processing and analysis. An aliquot of the whole blood was sent to the Centers for Disease Control and Prevention (CDC, USA) for additional analysis.

\section{DNA extraction}

DNA for the Nested PCR was extracted at the NMIMR from two $3 \mathrm{~mm}$ disks punched out of the DBS using the Chelex extraction method as previously described [35]. Whereas DNA for the PET-PCR was extracted at the CDC from $200 \mu \mathrm{L}$ of packed blood cell pellets using the QIAamp DNA Mini Kits (Qiagen, USA) according to the manufacturer's protocol. The DNA extracted from both procedures was either stored at $4{ }^{\circ} \mathrm{C}$ for immediate use or stored at $-20^{\circ} \mathrm{C}$ for later use.

\section{Nested PCR}

The Nested PCR amplification of the P. falciparum $18 S$ $r R N A$ gene was adapted from Singh et al. [36] with slight modification as previously reported [12]. Briefly, $200 \mathrm{nM}$ dNTPs, $2 \mathrm{mM} \mathrm{MgCl}$, $133 \mathrm{nM}$ each of forward (rPLU6) and reverse (rPLU5) primers (Additional file 1: Table S1) and $1 \mathrm{U}$ OneTaq DNA polymerase (NEB, UK) was used to amplify the $18 S r R N A$ gene from $5 \mu \mathrm{L}(\sim 20 \mathrm{ng})$ of DNA in the primary PCR. The secondary PCR was performed using similar concentrations of reagents as in the primary reaction mix; however, rFal1 (forward) and rFal2 (reverse) primers were used to amplify $1 \mu \mathrm{L}$ of the primary product. Genomic DNA from the 3D7 strain of P. falciparum (MRA 102G) was used as the positive control sample and distilled water (no template) served as the negative control sample. Positive and negative control samples were included in each PCR reaction set up. The amplified PCR products were separated alongside a 100 bp ladder (New England Biolabs, UK) on a 2\% agarose gel stained with Ethidium bromide. The gels were subsequently viewed under ultra-violet light using the FUSION-FX7 advanced (Vilber Lourmat, Germany) chemiluminescence documentation system. All PCR assays were performed using the Eppendorf Mastercycler Nexus thermal cycler (Eppendorf, UK).

\section{PET-PCR}

The multiplex PET-PCR assay was performed as previously described [27]. Briefly, the amplification of Plasmodium genus was performed in a $20 \mu \mathrm{L}$ reaction containing $2 \mu \mathrm{L}$ ( $\sim 20 \mathrm{ng}$ ) of each DNA template, TaqMan Environmental buffer 2.0 (Applied BioSystems, USA), $125 \mathrm{nM}$ each of forward and reverse primers (Additional file 1: Table S1) except for the P. falciparum HEXlabeled primer which was used at a $62.5 \mathrm{nM}$. The cycling parameters used were an initial denaturation at $95^{\circ} \mathrm{C}$ for $10 \mathrm{~min}$, followed by 45 cycles of denaturation at $95^{\circ} \mathrm{C}$ for $10 \mathrm{~s}$, annealing at $60^{\circ} \mathrm{C}$ for $40 \mathrm{~s}$ and an extension at $72{ }^{\circ} \mathrm{C}$ for $30 \mathrm{~s}$. Genomic DNA from the 3D7 strain of P. falciparum (CDC, USA) was used as a positive control. All assays were performed in duplicate and using the Agilent Mx3005pro thermal cycler (Agilent Technologies, USA).

\section{HRP2 bead assay}

The HRP2 concentrations $(\mathrm{pg} / \mathrm{mL})$ of each sample was determined using an HRP2 bead assay previously described by Rogier et al. [24]. Briefly, a $6 \mathrm{~mm}$ disc was punched out of the dried blood spot (DBS) and incubated overnight in $200 \mu \mathrm{L}$ of Buffer B (blocking buffer: 0.3\% Tween $20,0.5 \%$ bovine serum albumin, $0.1 \%$ casein, $0.5 \%$ polyvinyl alcohol, $0.5 \%$ polyvinylpyrrolidine, $0.05 \% \mathrm{NaN}_{3}$, and $0.01 \%$ Escherichia coli extract diluted 20 -fold). A total of $50 \mu \mathrm{L}$ of each test sample, Buffer B (background) and negative control sample (pooled plasma from 86 US blood donors who tested negative for malaria antigen and IgG and whose individual HRP2 concentrations have previously been evaluated) were added in duplicate on each plate. Following the assay incubation steps, $100 \mu \mathrm{L}$ PBS was added to each well and incubated at room temperature with shaking for $1 \mathrm{~min}$. The plate was subsequently read on a Luminex-200 machine (Luminex Corporation, USA) with a target of 50 beads per reading.

\section{Data analysis}

All samples that yielded visible fragments after agarose gel electrophoresis or CT values $<40$ (the CT cut off for the PET-PCR was set at 40) after real time PCR analysis were classified as positive for the particular PCR reaction. The HRP2 antigen concentration in a sample was determined as the mean threshold fluorescence intensity (MFI) - the background signal obtained from reading the buffer (blank). The cutoff value for a positive sample was the lognormal mean of the average negative control MFI (obtained from 86 malaria naïve individuals) +3 SD.

IBM SPSS version 20 was used to generate the descriptive statistics including median and to compare median age, haemoglobin and temperature between the two sites. Graph Pad Prism version 7 was used to determine Pearson Chi-Square for sex and parasite prevalence estimated by RDT, microscopy, Nested PCR and HRP2 bead assay, Mann-Whitney test for age and Cohen's kappa test was used to determine the level of agreement between parasite prevalence estimates determined by two different 
tests (RDT, microscopy, Nested PCR and HRP2 bead assay). The Wilson-Brown diagnostic test was used to determine the diagnostic properties of the Plasmodium detection tools.

Statistical significance was set as $\mathrm{P} \leq 0.05$ unless otherwise stated. Kappa values of $<0$ are classified as no agreement (disagreement), $0.0-0.20$ are classified as poor agreement; $0.21-0.40$ are classified as fair agreement; $0.41-0.60$ are classified as moderate agreement and values of $0.61-0.80$ classified as substantial agreement and $0.81-1.0$ as an almost perfect agreement [37].

\section{Results}

\section{Demographics}

Of the 194 participants, $105(54.1 \%)$ were residents of Obom, a high parasite prevalence area and 89 (45.9\%) were residents of Asutsuare, a low parasite prevalence area. There was no significant difference $(\mathrm{p}=0.652)$ in the distribution of males between the two study sites (53\% in Asutsuare and $49 \%$ in Obom) (Table 1) or in terms of age $(\mathrm{p}=0.109)$. The median (IQR) age of participants from Obom was $14(12-24.3)$ years and the median (IQR) age in Asutsuare was 16 (13-25.8) years.

\section{Estimation of parasite prevalence and density by microscopy}

A total of $19.1 \%(20 / 105)$ and $2.2 \%(2 / 89)$ of the samples were identified as positive for $P$. falciparum by microscopy in the high (Obom) and low (Asutsuare) transmission sites respectively (Table 1 ; Fig. $2 \mathrm{~A}, \mathrm{~B}$ ). One of the samples from Obom contained a mixture of $P$. falciparum and $P$. malariae (however, this was not confirmed by PCR). A higher number of $P$. falciparum parasite carriers

Table 1 Demographics of the study participants

\begin{tabular}{|c|c|c|c|}
\hline Parameters & Obom $(n=105)$ & Asutsuare $(n=89)$ & P-value \\
\hline \multicolumn{4}{|l|}{ Sex } \\
\hline Male/Female & $48 / 50^{*}$ & $43 / 38^{*}$ & $0.652^{\mathrm{a}}$ \\
\hline \multicolumn{4}{|l|}{ Age (years) } \\
\hline Median (Range) & $14(6.0-70.0)$ & $16(10.0-66.0)$ & $0.109^{b}$ \\
\hline \multicolumn{4}{|l|}{ Diagnostics } \\
\hline Microscopy & 20/105 (19.1) & $2 / 89(2.2)$ & $0.0002^{\mathrm{a}}$ \\
\hline HRP2-RDT & 39/101 (38.6) & - & - \\
\hline $\begin{array}{l}\text { HRP2 Bead } \\
\text { (Luminex) }\end{array}$ & $65 / 105$ (61.9) & 10/89 (11.2) & $0.0001^{c}$ \\
\hline PET-PCR & $63 / 105(60)$ & $5 / 89(5.6)$ & $0.001^{c}$ \\
\hline Nested PCR & 70/98 (71.4)¥ & $42 / 83(50.6) \neq$ & $0.0056^{c}$ \\
\hline
\end{tabular}

Yrs year, Min minimum, Max maximum, $n=$ total number of samples tested.

a Pearson Chi-Square

${ }^{\mathrm{b}}$ Mann Whitney (Two-tailed)

'Fisher's exact test. *a few samples had missing gender data. $¥=\mathrm{nPCR}$ was not perform for 7 samples; $\neq=\mathrm{nPCR}$ was not perform for 6 samples were detected in the high parasite prevalence setting (Obom) relative to the low parasite prevalence setting of (Asutsuare) (Pearson Chi-Square, $\mathrm{p}=0.0002$ ) (Table 1). Parasite density estimated as parasites per microlitre $(\mathrm{p} /$ $\mu \mathrm{L}$ ) blood from Obom ranged between $32 \mathrm{p} / \mu \mathrm{L}$ and 5080 $\mathrm{p} / \mu \mathrm{L}$ with a median (IQR) of $180(80-405) \mathrm{p} / \mu \mathrm{L}$, whilst in Asutsuare, both samples that tested positive by microscopy had a parasite density of $40 \mathrm{p} / \mu \mathrm{L}$ (Fig. 3A).

\section{Estimation of parasite prevalence based on antigen detection}

The HRP2-RDT identified a total of 38.6\% (39/101) of the samples collected from the high transmission area as positive. RDT results were not available for 4 samples from the high parasite prevalence area. None of the samples from the low parasite prevalence setting of Asutsuare tested positive by the HRP2 RDT (Fig. 2B; Table 1).

Detection of the $P$. falciparum HRP2 antigen using the HRP2 bead assay was significantly higher in Obom (61.9\%) when compared to Asutsuare (11.2\%), $\mathrm{p}<0.0001$. The P. falciparum HRP2 antigen levels of samples in Obom ranged from 226.0 to $820,368 \mathrm{pg} / \mathrm{mL}$, with a median of 4689.0 and $49.4 \mathrm{pg} / \mathrm{mL}$ to $44,980 \mathrm{pg} / \mathrm{mL}$ with a median of $236.4 \mathrm{pg} / \mathrm{mL}$ in Asutsuare. The median HRP2 antigen levels in samples from Obom $(4689.0 \mathrm{pg} / \mathrm{mL})$ was significantly higher than samples from Asutsuare with median HRP2 antigen level of 236.4 pg/mL (Mann Whitney test, $\mathrm{p}<0.0001$ ) (Fig. 3B).

\section{Estimation of parasite prevalence based on molecular tests} In the high transmission setting (Obom), 60\% (63/105) of the samples tested positive for $P$. falciparum by PET-PCR, with parasite density estimates ranging from $0.4 \mathrm{p} / \mu \mathrm{L}$ to $7,002 \mathrm{p} / \mu \mathrm{L}$, with a median of $37.1 \mathrm{p} / \mu \mathrm{L}$. In the low transmission setting (Asutsuare), 5.6\% (5/89) of the samples tested positive for $P$. falciparum, with parasite density estimates ranging from 5.0 to $331.7 \mathrm{p} / \mu \mathrm{L}$, with a median of $14.0 \mathrm{p} / \mu \mathrm{L}$ (Fig. 3C). Although a significantly higher number of parasites were detected in the high transmission setting (Obom) than in the low transmission setting (Asutsuare), (Fisher's exact test, $\mathrm{p}<0.001$ ), there was no significant difference between the estimated parasite densities of the two sites when their median parasite density was compared (Mann Whitney test, $\mathrm{p}=0.8879$ ).

\section{Illustration of relationships among sensitive detection methods by areas}

There were 8 and 12 samples from the high transmission setting (Obom) that tested positive and negative respectively for $P$. falciparum by all the five methods tested (Additional file 1: Fig. S3). In the low transmission setting, no sample was identified as positive by all the 
A

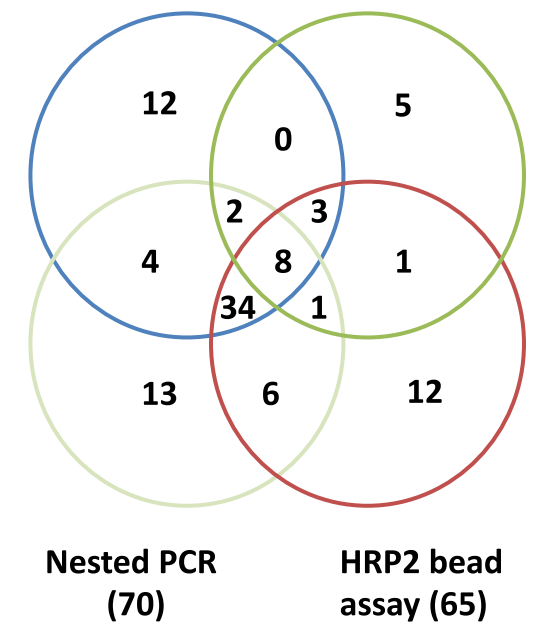

B PET-PCR (5) Microscopy (2)

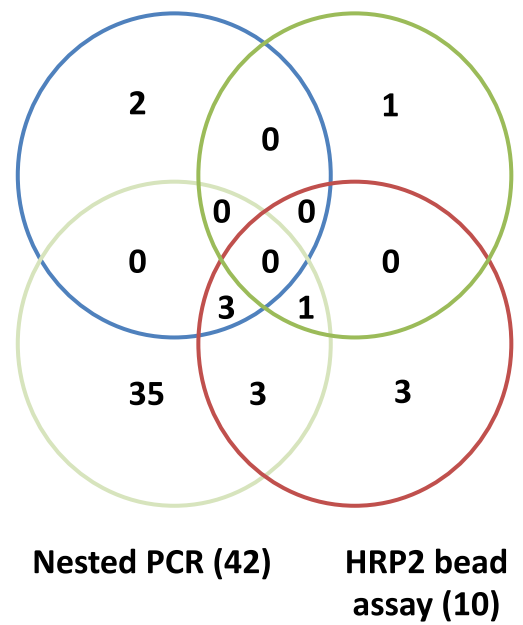

Fig. 2 Comparisons of PET-PCR, nPCR and the HRP2 bead assay detection tools to Microscopy (Gold standard). A Venn diagram illustrating the number of positive parasites by the four methods, A High transmission site, the four methods identified 8 samples as positive for the parasites, 6 positive samples between Nested PCR and HRP2 bead assay, and 0 between Microscopy and HRP2 bead assay, and 4 positive samples between PET-PCR and N-PCR. B Low transmission, the four methods did not identified any samples as positive for the parasites, 3 positive samples between Nested PCR and HRP2 bead assay, and no positive parasite between Microscopy and HRP2 bead assay, and also no positive sample between PET-PCR and Nested PCR

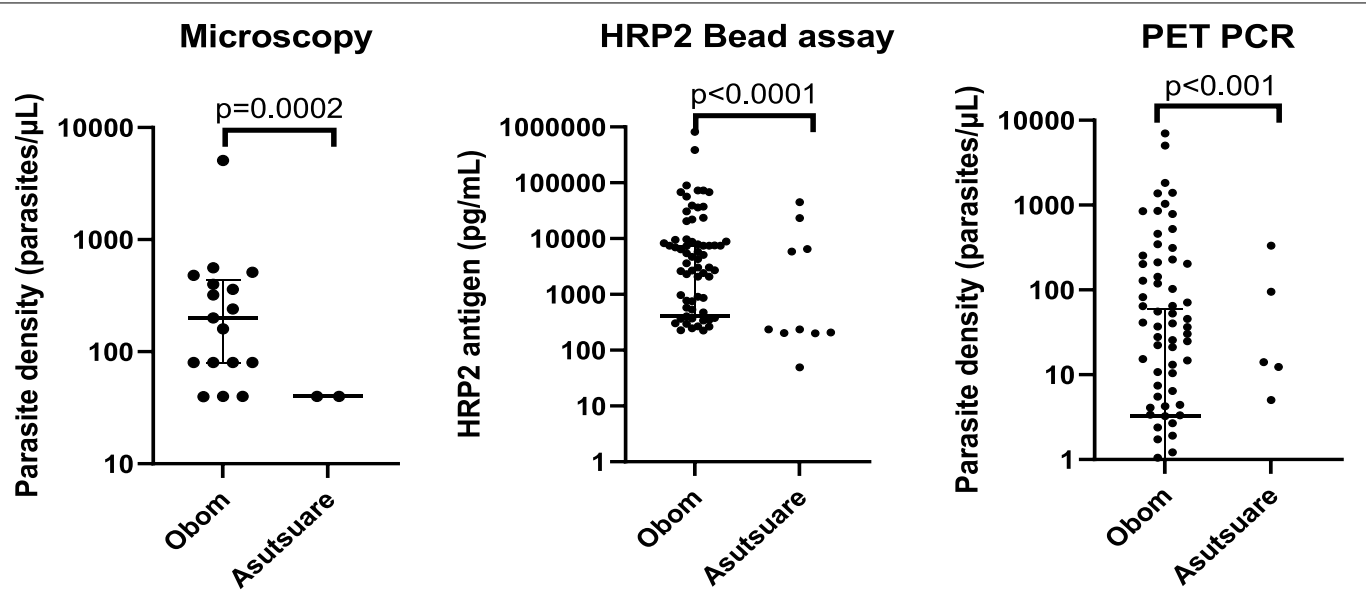

Fig. 3 Parasite density determined by different tools. The median (IQR) parasite density of samples that tested positive for P. falciparum by microscopy (a), the median (IQR) HRP2 antigen content of the samples estimated using the HRP2 bead assay (b) and PET-PCR (c) from each site. Significant differences were observed in values obtained using microscopy (a) and the bead assay (b) but not by PET-PCR (c) when samples from Obom were compared to those from Asutusare

methods, whilst 38 samples were identified as negative by all five tests (Additional file 1: Fig. S1).

A total of $71.4 \%(45 / 63)$ of the PET-PCR positive samples and $28.5 \%(12 / 42)$ of the PET-PCR negative samples from the high transmission setting (Obom) tested positive by the HRP2 bead assay (Fig. 2, Additional file 1: Fig. S1). Whilst in Asutsuare, 80\% (4/5) of the PET-PCR positive samples and $7.1 \%(6 / 84)$ of the PET-PCR negative samples tested positive by the HRP2 bead assay (Fig. 2, Additional file 1: Fig. S2).

\section{Comparison of detection tools}

In the high transmission setting (Obom), parasite prevalence estimated by Nested PCR was significantly higher than that estimated by PET-PCR and the HRP2 bead assay (Pearson Chi square $=13.06$ and 6.76, respectively, $\mathrm{p}<0.001$ for both), but parasite prevalence estimated by 
the HRP2 bead assay and PET-PCR were similar (Pearson Chi square $=31.89$ and $\mathrm{p}>0.05$ ) (Fig. 2A, Additional file 1: Table S3).

In the low transmission setting, parasite prevalence estimated by the HRP2 bead assay was significantly higher than that recorded by PET-PCR (Fisher's Exact Test $\mathrm{p}<0.000$ ) (Fig. 2B, Additional file 1: Table S1) and the difference between parasite prevalence estimated by both Nested PCR and PET-PCR on the one hand and Nested PCR and the HRP2 bead assay on the other were similar (Fisher's Exact Test $\mathrm{p}=1.000$ and 0.156 , respectively).

The HRP2 bead assay, identified a significantly higher number of $P$. falciparum positive samples compared to the HRP2 based RDT kit in the high malaria transmission setting (Pearson Chi-Square $=17.22, \mathrm{p}<0.001)($ Table 1 ,

Table 2 Inter-rater agreement between different detection tools

\begin{tabular}{lcl}
\hline Parameter & $\begin{array}{l}\text { Obom } \\
\text { Kappa (p value) }\end{array}$ & $\begin{array}{l}\text { Asutsuare } \\
\text { Kappa (p value) }\end{array}$ \\
\hline RDT vs HRP2 bead assay & $0.262(0.004)^{*}$ & \\
PET-PCR vs Nested PCR & $0.348(0.001)^{*}$ & $0.022(0.665)$ \\
PET-PCR vs HRP2 bead assay & $0.560(0.000)$ & $0.496(0.000)$ \\
Microscopy vs RDT & $0.194(0.028)^{*}$ & - \\
Microscopy vs PET-PCR & $0.040(0.537)$ & $-0.033(0.727)$ \\
Microscopy vs HRP2 bead assay & $0.027(0.663)$ & $0.134(0.079)^{*}$ \\
Microscopy vs Nested PCR & $-0.014(0.808)$ & $-0.034(0.768)$ \\
Nested PCR vs RDT & $0.186(0.019)^{*}$ & - \\
Nested PCR vs PET-PCR & $0.348(0.001)^{*}$ & $0.022(0.665)$ \\
Nested PCR vs HRP2 bead assay & $0.248(0.012)^{*}$ & $0.117(0.084)$ \\
Nested PCR vs Microscopy & $-0.009(0.874)$ & $0.047(0.157)$ \\
\hline
\end{tabular}

*Significant $p$ value; vs, versus; No statistics could be computed for RDT vs the HRP2 bead assay in Asutsuare because no RDT positive samples were identified in Asutsuare
Additional file 1: Table S3). Comparisons could not be made in the low transmission site, as no sample tested positive by HRP2 RDT (Table 1 and Additional file 1: Table S3). Nested PCR identified a significantly higher number of positive samples compared to PET-PCR in both the high transmission setting, Obom (Pearson ChiSquare $=13.06, \mathrm{p}<0.001)$ (Table 1, Fig. 2A) and the low transmission setting, Asutsuare (Fisher's Exact Test, $\mathrm{p}<0.001)$.

\section{Agreement between diagnostic tests}

Microscopy is generally referred to as the gold standard diagnostic test for malaria. When results from the microscopy read out by the microscopists used in this study was set as the reference test (Table 2), the level of agreement between microscopy and the PET-PCR and the HRP2 bead assay tests in Obom was poor, with a fair agreement observed between results obtained by microscopy and RDT. In Asutsuare, the interrater agreement between microscopy and both PET-PCR and Nested PCR was poor but the agreement between microscopy and the HRP2 bead assay was fair. All the poor agreements were not significant, whilst the fair agreements were significant. There was no agreement between microscopy and Nested PCR in both Obom and Asutsuare (Table 2).

When Cohen's kappa analysis (Table 2) was repeated with Nested PCR set as the reference, there was a poor agreement between Nested PCR and RDT but a fair agreement between Nested PCR and PET-PCR and the HRP2 bead assay in Obom, whilst in Asutsuare, all the agreements were poor. Excluding the microscopy data, all the agreements in Obom were significant whilst those in Asustuare were not significant (Table 2). In comparing diagnostic methods that measure similar parasite

Table 3 Diagnostic properties of Nested PCR, PET-PCR and HRP2 bead assay

\begin{tabular}{|c|c|c|c|c|}
\hline & $\begin{array}{l}\text { Sensitivity } \\
(95 \% \mathrm{Cl})\end{array}$ & $\begin{array}{l}\text { Specificity } \\
(95 \% \mathrm{Cl})\end{array}$ & $\begin{array}{l}\text { PPV } \\
(95 \% \mathrm{Cl})\end{array}$ & $\begin{array}{l}\text { NPV } \\
(95 \% \mathrm{Cl})\end{array}$ \\
\hline \multicolumn{5}{|l|}{ Obom } \\
\hline HRP2 bead assay vs Nested PCR & $\begin{array}{l}0.4815 \\
(0.3989 \text { to } 0.5651)\end{array}$ & $\begin{array}{l}0.4118 \\
(0.3026 \text { to } 0.5304)\end{array}$ & $\begin{array}{l}0.619 \\
(0.5235 \text { to } 0.7062)\end{array}$ & $\begin{array}{l}0.2857 \\
(0.2057 \text { to } 0.3819)\end{array}$ \\
\hline HRP2 bead assay vs PET-PCR & $\begin{array}{l}0.5078 \\
(0.4222 \text { to } 0.5929)\end{array}$ & $\begin{array}{l}0.5122 \\
(0.4059 \text { to } 0.6174)\end{array}$ & $\begin{array}{l}0.619 \\
(0.5235 \text { to } 0.7062)\end{array}$ & $\begin{array}{l}0.4 \\
(0.3114 \text { to } 0.4956)\end{array}$ \\
\hline Nested PCR vs PET-PCR & $\begin{array}{l}0.5263 \\
\text { (0.4419 to } 0.6092)\end{array}$ & $\begin{array}{l}0.6 \\
(0.4829 \text { to } 0.7067)\end{array}$ & $\begin{array}{l}0.7143 \\
(0.6181 \text { to } 0.7943)\end{array}$ & $\begin{array}{l}0.4 \\
(0.3114 \text { to } 0.4956)\end{array}$ \\
\hline \multicolumn{5}{|l|}{ Asutsuare } \\
\hline HRP2 bead assay vs Nested PCR & $\begin{array}{l}0.1923 \\
(0.1080 \text { to } 0.3190)\end{array}$ & $\begin{array}{l}0.3417 \\
(0.2629 \text { to } 0.4303)\end{array}$ & $\begin{array}{l}0.1124 \\
(0.06219 \text { to } 0.1946)\end{array}$ & $\begin{array}{l}0.494 \\
\text { (0.3891 to } 0.5994)\end{array}$ \\
\hline HRP2 bead assay vs PET-PCR & $\begin{array}{l}0.6667 \\
\text { (0.4171 to } 0.8482 \text { ) }\end{array}$ & $\begin{array}{l}0.5153 \\
(0.4391 \text { to } 0.5908)\end{array}$ & $\begin{array}{l}0.1124 \\
(0.06219 \text { to } 0.1946)\end{array}$ & $\begin{array}{l}0.9438 \\
(0.8751 \text { to } 0.9758)\end{array}$ \\
\hline Nested PCR vs PET-PCR & $\begin{array}{l}0.1064 \\
(0.04630 \text { to } 0.2259)\end{array}$ & $\begin{array}{l}0.328 \\
(0.2519 \text { to } 0.4144)\end{array}$ & $\begin{array}{l}0.05618 \\
\text { (0.02423 to } 0.1249)\end{array}$ & $\begin{array}{l}0.494 \\
\text { (0.3891 to } 0.5994)\end{array}$ \\
\hline
\end{tabular}

PPV Positive Predictive Value, NPV Negative Predictive value. The values reported are relative frequency with the $95 \%$ confidence interval (95\% Cl) 
features, HRP2 antigen (RDT and the HRP2 bead assay) and parasite DNA (Nested PCR and PET-PCR), fair and significant agreements were observed only for the samples collected from the high transmission setting (Obom) (Table 2).

A crosstabulation analysis between PET-PCR and the HRP2 bead assay found that the two methods agreed moderately and significantly in Obom, Cohen kappa value $=0.560, p=0.000$ and in Asutsuare, Cohen kappa value $=0.496, \mathrm{p}=0.000)($ Table 2$)$.

\section{Sensitivity and specificity of diagnostic methods}

The diagnostic properties of the three highly sensitive diagnostic tools were evaluated. In the high transmission setting (Obom), the diagnostic properties of Nested PCR, PET-PCR and the HRP2 bead assay were similar, whilst in the low transmission setting the diagnostic properties of only the HRP2 bead assay and PET-PCR were similar (Table 3 ). The sensitivity and specificity PET-PCR and the HRP2 bead assay at detecting asymptomatic $P$. falciparum carriage were similar in both the high (Obom) and low (Asutsuare) malaria transmission setting.

\section{Discussion}

This study independently utilized five different diagnostic tools, PET-PCR, an HRP2 bead assay in addition to commonly used HRP2 RDT, microscopy and Nested PCR to determine the presence of $P$. falciparum harboured as asymptomatic infections in two communities with varied malaria parasite prevalence in southern Ghana. Asymptomatic malaria infections are usually characterized by low and submicroscopic parasite densities [38] and depending on the transmission intensity of the area, can contain lower than 100 parasites per microlitre ( $\mathrm{p} /$ $\mu \mathrm{L})[39,40]$. Relying solely on microscopy to detect the presence of Plasmodium parasites contained in such low density infections will likely result in missing many infections. Although microscopy, RDTs and Nested PCR are routinely used to detect malaria parasites in Ghana, PETPCR and the HRP2 bead assay are known to be more sensitive than microscopy at detecting low density parasitaemia $[24,41]$ are rarely used. The sensitivities of various combinations of commonly used malaria diagnostic tools have been compared in different malaria endemic countries, including Ghana [5], none of the studies conducted in Ghana has compared the performance of PET-PCR and an HRP2 bead assay to microscopy, an HRP2-based RDT and Nested PCR at determining malaria parasite prevalence in different settings in Ghana. This study was conducted to evaluate the performance of malaria diagnostic tools, especially PET-PCR and the HRP2 bead assay as effective tools to detect asymptomatic malaria parasite carriage in settings with varying parasite prevalence in Ghana.

In this study, microscopy and HRP2-based RDT, the most commonly used malaria diagnostic tests in community surveillance studies in malaria endemic countries [42] produced the lowest estimates of asymptomatic parasite carriage in both the high and low malaria parasite prevalence settings. This was not surprising as the parasite densities of infections in samples from even the high parasite prevalence setting were very low. Asymptomatic infections are noted to contain low (submicroscopic) parasite densities [43], below the limit of detection of both microscopy and RDT kits [42].

The HRP2 RDT kit detected a higher number of samples as positive for $P$. falciparum than microscopy in the high transmission setting, but a reverse trend was observed in the low transmission setting. One likely reason for these results could be that the HRP2 antigen concentrations measured in samples from the high parasite prevalence setting were often higher and can be detected by the RDT than in the low parasite prevalence setting where it is below the detection limit of the RDT [51, 52]. Higher levels of HRP2 antigen could also result from a longer duration of antigen persistence in the high parasite prevalence setting due to more frequent infection. This would account for the higher positivity rates detected compared to microscopy in Obom but not in the low parasite prevalence setting (Asutsuare). The persistence of the HRP2 antigen after the clearance of infecting parasites is a well-known phenomenon $[44,45]$. Consequently, HRP2 based malaria RDT kits may test positive for HRP2 antigens in the absence of an active infection. Additionally, as demonstrated in the study sites described here, parasite densities in low transmission settings are generally low and likely to be below the limit of detection of the RDT and microscopy especially in the off-peak season [31].

The diagnostic properties of PET-PCR, Nested PCR and the HRP2 bead assay was similar in the high parasite prevalence setting, and resulted in similar estimates of parasite carriage, however, the level of agreement among the three tests was low. This observation may be due to differences in limits of detection, assay targets and other fundamental differences between the methods. Persistence of HRP2 antigen for up to four weeks following a resolved $P$. falciparum infection can result in false positive HRP2 bead assay results, whilst parasites with deletions in the Pfhrp2 gene (not tested in this study) can cause false negative tests [46-48]. Nested PCR protocols generally have much higher numbers of amplification cycles compared to real time PCR protocols including PET-PCR and as such are likely to detect and amplify lower template concentrations than real time 
PCR. Nested PCR has previously been found to be more sensitive than PET PCR $[49,50]$. However, the increased number of steps involved in Nested PCR make it more tedious and prone to contaminations and other operator errors that can increase the number of false negative as well as false positive test results compared with real time PCR processes.

When the results obtained from PET-PCR and Nested PCR, both DNA-detecting tools were compared to the results from the HRP2 bead assay, there was a much higher level of agreement between PET-PCR and the HRP2 bead assay. A possible explanation for this could be that PET-PCR and the HRP2 bead assay have a similar parasitaemia threshold of approximately two parasites per microliter [24], which is higher than that of Nested PCR. However, both the HRP2 bead assay and PET-PCR are quantitative, require fewer processing steps, and are faster processes than Nested PCR.

\section{Limitations}

This pilot study was not formally designed as a diagnostic study. The different diagnostic tests used in this study detect different parasite components and also have varying limits of detection. The samples used in this study were collected during the off-peak malaria season where parasite densities are generally low and thus would require diagnostic tests with a low limit of detection and high sensitivity to detect. Also, deletions in the Pfhrp2 gene, which were not determined in the study could affect the sensitivity of both the HRP2 RDT and the HRP2 bead assay results.

\section{Conclusion}

Nested PCR exhibited the highest sensitivity by identifying the highest prevalence of asymptomatic $P$. falciparum in both the high and low parasite prevalence settings. However, parasite prevalence estimated by the HRP2 bead assay and PET-PCR had the highest level of inter-rater agreement relative to all the other tools tested and have the advantage of requiring fewer processing steps and producing quantitative results relative to Nested PCR. These advantages make PET-PCR and the HRP2 bead assay very useful tools for detecting and estimating malaria parasite density especially amongst asymptomatic individuals during community surveys.

\section{Abbreviations}

RDT: Rapid diagnostic test; PET-PCR: Photo-induced electron transfer polymerase chain reaction; WBCs: White blood cells; PD: Parasite density; $\mathrm{p} / \mu \mathrm{L}$ : Parasites per microlitre.

\section{Supplementary Information}

The online version contains supplementary material available at https://doi. org/10.1186/s12936-022-04078-w.

Additional file 1: Table S1. Primer properties. Table S2. Summary of parasite prevalence data. Table S3. Comparison between the three sensitive methods in the two study sites. Figure S1. Illustrative Flow chart showing the total number of positive and negative samples detected by the combination of 5 different of $P$. falciparum diagnosis tools in the high and low malaria transmission setting. Figure S2. Illustrative Flow chart showing asymptomatic malaria diagnosis by the three sensitive diagnostic tools in the high transmission setting. Figure S3. Illustrative Flow chart showing asymptomatic malaria diagnosis by the three sensitive diagnostic tools in the low transmission setting.

\section{Acknowledgements}

The authors are grateful to all the study participants as well as the guardians of the minors who participated in the study for granting consent. The authors thank Mr Festus Acquah of the NMIMR for critical review of the manuscript.

\section{Disclaimer}

The findings and conclusions presented in this report are those of the authors and do not necessarily reflect the official position of the Centers for Disease Control and Prevention.

\section{Authors' contributions}

LEA, MA and ER designed the study. AL collected the samples. HBA, ZA, ER and SA performed the experiments. LEA, KKA and HBA performed the statistical analysis. HBA, LEA, KKA, MA and ER contributed to writing the manuscript. All authors read and approved the final manuscript.

\section{Funding}

This project was supported in part by Bill and Melinda Gates Foundation under the Postdoctoral and Postgraduate Training in Infectious disease research at Noguchi Memorial Institute for Medical Research awarded to AL and the US Centers for Disease Control and Prevention.

\section{Availability of data and materials}

All data generated or analysed during this study are included in this published article.

\section{Declarations}

\section{Ethics approval and consent to participate}

Research Approval was obtained from the Institutional Review Board (IRB) of the Noguchi Memorial Institute for Medical Research (NMIMR). Written informed consent was obtained from study participants as well as the parents or guardians of participants who were minors before they were enrolled onto the study.

\section{Consent for publication}

Not applicable.

\section{Competing interests}

The authors declare that they have no competing interests.

\section{Author details}

${ }^{1}$ Immunology Department, Noguchi Memorial Institute for Medical Research (NMIMR), University of Ghana, Accra, Ghana. ${ }^{2}$ School of Life Science and Technology, University of Electronic Science and Technology of China, Chengdu, China. ${ }^{3}$ The Centers for Disease Control and Prevention, Center for Global Health, Division of Parasitic Diseases and Malaria, Malaria Branch, Atlanta, GA, USA.

Received: 11 August 2021 Accepted: 6 February 2022

Published online: 19 February 2022 


\section{References}

1. Lindblade KA, Steinhardt L, Samuels A, Kachur SP, Slutsker L. The silent threat: asymptomatic parasitemia and malaria transmission. Expert Rev Anti Infect Ther. 2013;11:623-39.

2. Filipe JA, Riley EM, Drakeley CJ, Sutherland CJ, Ghani AC. Determination of the processes driving the acquisition of immunity to malaria using a mathematical transmission model. PLoS Comput Biol. 2007:3:e255.

3. Bousema T, Okell L, Felger I, Drakeley C. Asymptomatic malaria infections: detectability, transmissibility and public health relevance. Nat Rev Microbiol. 2014;12:833-40.

4. Okell LC, Bousema T, Griffin JT, Ouédraogo AL, Ghani AC, Drakeley CJ. Factors determining the occurrence of submicroscopic malaria infections and their relevance for control. Nat Commun. 2012;3:1237.

5. Ayanful-Torgby R, Quashie NB, Boampong JN, Williamson KC, Amoah LE. Seasonal variations in Plasmodium falciparum parasite prevalence assessed by varying diagnostic tests in asymptomatic children in southern Ghana. PLoS One. 2018;13:e0199172.

6. Moody A. Rapid diagnostic tests for malaria parasites. Clin Microbiol Rev. 2002;15:66-78.

7. Gilles HM, Warrell DA. Bruce-Chwatt's Essential Malariology. 3rd ed. London: Edward Arnold; 1993

8. WHO. Giemsa staining of malaria blood films. In: Malaria microscopy standard operating procedure - MM-SOP-07A. Manilla, Regional Office for the Western Pacific, World Health Organization, 2016.

9. Mathison BA, Pritt BS. Update on malaria diagnostics and test utilization. J Clin Microbiol. 2017;55:2009-17.

10. Berzosa P, De Lucio A, Romay-Barja M, Herrador Z, Gonzalez V, Garcia L, et al. Comparison of three diagnostic methods (microscopy, RDT, and PCR) for the detection of malaria parasites in representative samples from Equatorial Guinea. Malar J. 2018;17:333.

11. Rubio J, Benito A, Berzosa P, Roche J, Puente S, Subirats M, et al. Usefulness of seminested multiplex PCR in surveillance of imported malaria in Spain. J Clin Microbiol. 1999;37:3260-4.

12. Adjah J, Fiadzoe B, Ayanful-Torgby R, Amoah LE. Seasonal variations in Plasmodium falciparum genetic diversity and multiplicity of infection in asymptomatic children living in southern Ghana. BMC Infect Dis. 2018;18:432.

13. Lamptey H, Ofori MF, Kusi KA, Adu B, Owusu-Yeboa E, Kyei-Baafour E, et al. The prevalence of submicroscopic Plasmodium falciparum gametocyte carriage and multiplicity of infection in children, pregnant women and adults in a low malaria transmission area in Southern Ghana. Malar J. 2018:17:331.

14. Palmer CJ, Lindo JF, Klaskala WI, Quesada JA, Kaminsky R, Baum MK, et al. Evaluation of the OptiMAL test for rapid diagnosis of Plasmodium vivax and Plasmodium falciparum malaria. J Clin Microbiol. 1998;36:203-6.

15. Beadle C, Long GW, Weiss WR, McElroy PD, Maret SM, Oloo AJ, et al. Diagnosis of malaria by detection of Plasmodium falciparum HRP-2 antigen with a rapid dipstick antigen-capture assay. Lancet. 1994;343:564-8.

16. Garcia M, Kirimoama S, Marlborough D, Leafasia J, Rieckmann KH. Immunochromatographic test for malaria diagnosis. Lancet. 1996;347:1549.

17. Bechem NN, Leke RF, Tietche F, Taylor DW. Evaluation of a rapid test for histidine rich protein 2 for diagnosis of Plasmodium falciparum infection in Cameroonian children. Trans R Soc Trop Med Hyg. 1999;93:46.

18. Cunningham J, Jones S, Gatton ML, Barnwell JW, Cheng Q, Chiodini PL, et al. A review of the $\mathrm{WHO}$ malaria rapid diagnostic test product testing programme (2008-2018): performance, procurement and policy. Malar J. 2019;18:387.

19. Ochola L, Vounatsou P, Smith T, Mabaso M, Newton C. The reliability of diagnostic techniques in the diagnosis and management of malaria in the absence of a gold standard. Lancet Infect Dis. 2006;6:582-8.

20. Gatton ML, Rees-Channer RR, Glenn J, Barnwell JW, Cheng Q, Chiodini PL, et al. Pan-Plasmodium band sensitivity for Plasmodium falciparum detection in combination malaria rapid diagnostic tests and implications for clinical management. Malar J. 2015:14:115

21. Erdman LK, Kain KC. Molecular diagnostic and surveillance tools for global malaria control. Travel Med Infect Dis. 2008:6:82-99.

22. Humar A, Ohrt C, Harrington MA, Pillai D, Kain KC. Parasight F test compared with the polymerase chain reaction and microscopy for the diagnosis of Plasmodium falciparum malaria in travelers. Am J Trop Med Hyg. 1997;56:44-8.
23. Berhane A, Russom M, Bahta I, Hagos F, Ghirmai M, Uqubay S. Rapid diagnostic tests failing to detect Plasmodium falciparum infections in Eritrea: an investigation of reported false negative RDT results. Malar J. 2017;16:105.

24. Rogier E, Plucinski M, Lucchi N, Mace K, Chang M, Lemoine JF, et al. Beadbased immunoassay allows sub-picogram detection of histidine-rich protein 2 from Plasmodium falciparum and estimates reliability of malaria rapid diagnostic tests. PLoS One. 2017;12:e0172139.

25. Fouda GG, Leke RF, Long C, Druilhe P, Zhou A, Taylor DW, et al. Multiplex assay for simultaneous measurement of antibodies to multiple Plasmodium falciparum antigens. Clin Vaccine Immunol. 2006;13:1307-13.

26. Ambrosino E, Dumoulin C, Orlandi-Pradines E, Remoue F, Toure-Baldé A, Tall A, et al. A multiplex assay for the simultaneous detection of antibodies against 15 Plasmodium falciparum and Anopheles gambiae saliva antigens. Malar J. 2010;9:317.

27. Lucchi NW,Narayanan J, Karell MA, Xayavong M, Kariuki S, Dasilva AJ, et al. Molecular diagnosis of malaria by photo-induced electron transfer fluorogenic primers: PET-PCR. PLoS One. 2013;8:e56677.

28. Acquah FK, Lo AC, Akyea-Mensah K, Abagna HB, Faye B, Theisen M, et al. Stage-specific Plasmodium falciparum immune responses in afebrile adults and children living in the Greater Accra Region of Ghana. Malar J. 2020;19:64.

29. Acquah FK, Donu D, Bredu D, Eyia-Ampah S, Amponsah JA, Quartey J, et al. Asymptomatic carriage of Plasmodium falciparum by individuals with variant blood groups and haemoglobin genotypes in southern Ghana. Malar J. 2020;19:217

30. Adu B, Dodoo D, Adukpo S, Hedley PL, Arthur FK, Gerds TA, et al. Fc gamma receptor IIIB (FcgammaRIIIB) polymorphisms are associated with clinical malaria in Ghanaian children. PLoS One. 2012;7:e46197.

31. Amoah LE, Abagna HB, Kyea-Mensah K, Lo AC, Kusi KA, Gyan BA. Characterization of anti-EBA175RIII-V in asymptomatic adults and children living in communities in the Greater Accra Region of Ghana with varying malaria transmission intensities. BMC Immunol. 2018;19:34.

32. WHO. World malaria report 2015. Geneva, World Health Organization, 2016.

33. WHO. Malaria Microscopy Quality Assurance Manual. Malaria Microscopy. Geneva, World Health Organization, 2015.

34. WHO. Malaria parasite counting. In: Malaria microscopy standard operating procedure - MM-SOP-09. Geneva,World Health Organization, 2016.

35. Amoah LE, Opong A, Ayanful-Torgby R, Abankwa J, Acquah FK. Prevalence of G6PD deficiency and Plasmodium falciparum parasites in asymptomatic school children living in southern Ghana. Malar J. 2016:15:388.

36. Singh B, Bobogare A, Cox-Singh J, Snounou G, Abdullah MS, Rahman HA. A genus- and species-specific nested polymerase chain reaction malaria detection assay for epidemiologic studies. Am J Trop Med Hyg. 1999;60:687-92.

37. Altman DG. Practical statistics for medical research. London: Chapman and Hall; 1991.

38. Slater HC, Ross A, Felger I, Hofmann NE, Robinson L, Cook J, et al. The temporal dynamics and infectiousness of subpatent Plasmodium falciparum infections in relation to parasite density. Nat Commun. 2019;10:1433.

39. Mcguinness D, Koram K, Bennett S, Wagner G, Nkrumah F, Riley E. Clinical case definitions for malaria: clinical malaria associated with very low parasite densities in African infants. Trans R Soc Trop Med Hyg. 1998:92:527-31.

40. Wagner G, Koram K, McGuinness D, Bennett S, Nkrumah F, Riley E. High incidence of asymptomatic malara infections in a birth cohort of children less than one year of age in Ghana, detected by multicopy gene polymerase chain reaction. Am J Trop Med Hyg. 1998;59:115-23.

41. Talundzic E, Maganga M, Masanja IM, Peterson DS, Udhayakumar V, Lucchi NW. Field evaluation of the photo-induced electron transfer fluorogenic primers (PET) real-time PCR for the detection of Plasmodium falciparum in Tanzania. Malar J. 2014;13:31

42. Florey $L$, Measures of malaria parasitemia prevalence in national surveys: agreement between rapid diagnostic tests and microscopy. In: DHS Analytical Studies No. 43. 2014, USAID: Maryland, USA.

43. Niang M, Thiam LG, Sane R, Diagne N, Talla C, Doucoure S, et al. Substantial asymptomatic submicroscopic Plasmodium carriage during dry season in low transmission areas in Senegal: Implications for malaria control and elimination. PLoS One. 2017;12:e0182189. 
44. Dalrymple U, Arambepola R, Gething PW, Cameron E. How long do rapid diagnostic tests remain positive after anti-malarial treatment? Malar J. 2018;17:228.

45. Mouatcho JC, Goldring JP. Malaria rapid diagnostic tests: challenges and prospects. J Med Microbiol. 2013;62:1491-505.

46. Amoah LE, Abuaku B, Bukari AH, Dickson D, Amoako EO, Asumah G, et al. Contribution of $P$. falciparum parasites with Pfhrp 2 gene deletions to false negative PfHRP 2 based malaria RDT results in Ghana: a nationwide study of symptomatic malaria patients. PLoS One. 2020;15:e0238749.

47. Cunningham J. Update on Plasmodium falciparum hrp2/3 gene deletions. Geneva: World Health Organization; 2017.

48. WHO. False-negative RDT results and implications of new reports of $P$. falciparum histidine-rich protein 2/3 gene deletions. Geneva, World Health Organization, 2016

49. Akerele D, Ljolje D, Talundzic E, Udhayakumar V, Lucchi NW. Molecular diagnosis of Plasmodium ovale by photo-induced electron transfer fluorogenic primers: PET-PCR. PLoS One. 2017;12:e0179178.

50. Lucchi NW, Karell MA, Journel I, Rogier E, Goldman I, Ljolje D, et al. PETPCR method for the molecular detection of malaria parasites in a national malaria surveillance study in Haiti, 2011. Malar J. 2014:13:462.

51. Emily NR, Jen CCH, Issaka S, Sara AH, Mahamadoun HA, Merepen AG, et al. Ultra-sensitive RDT performance and antigen dynamics in a hightransmission Plasmodium falciparum setting in Mali. Malar J. 2020;19:323.

52. Matthew EC, Bachir A, Céline L, Nathan S, Iza C, Roberto DT, et al. Clinical diagnostic evaluation of HRP2 and pLDH-based rapid diagnostic tests for malaria in an area receiving seasonal malaria chemoprevention in Niger. Malar J. 2019;18:443.

\section{Publisher's Note}

Springer Nature remains neutral with regard to jurisdictional claims in published maps and institutional affiliations.

- fast, convenient online submission

- thorough peer review by experienced researchers in your field

- rapid publication on acceptance

- support for research data, including large and complex data types

- gold Open Access which fosters wider collaboration and increased citations

- maximum visibility for your research: over $100 \mathrm{M}$ website views per year

At BMC, research is always in progress.

Learn more biomedcentral.com/submissions 